\title{
The human CD40 agonistic antibody ADC-1013 generates immune mediated anti-tumor effects in syngeneic tumor models in hCD40 transgenic mice
}

\author{
Sara M Mangsbo ${ }^{1}$, Niina Veitonmäki ${ }^{2}$, Erika Gustfson ${ }^{1}$, Karin Enell Smith², Christina Furebring ${ }^{2}$, Per Norlén², \\ Malin Lindstedt ${ }^{3}$, Thomas H Tötterman ${ }^{1}$, Peter Ellmark ${ }^{2^{*}}$ \\ From Society for Immunotherapy of Cancer 29th Annual Meeting \\ National Harbor, MD, USA. 6-9 November 2014
}

Local activation of costimulatory pathways by e.g. CD40 activation has been shown to generate powerful systemic anti-tumor responses. Here we report significant antitumor effects obtained with an optimized fully human agonistic CD40 antibody, ADC-1013, in two syngeneic tumor models.

An hCD40 transgenic mouse (hCD40tg) strain was used to evaluate the immune mediated anti-tumor effects of ADC-1013. Dendritic cells obtained from hCD40tg mice were hCD40 positive and could be activated by stimulation with ADC-1013 to a similar extent as human monocyte derived dendritic cells. Furthermore, stimulation of dendritic cells from hCD40tg mice in vitro, with ADC-1013, induced antigen specific $\mathrm{T}$ cell activation.

Two different syngeneic tumor models, hCD40 negative MB49 bladder cancer and hCD40 positive B16.F10.hCD40 + melanoma, was used to demonstrate anti-tumor effects. Subcutaneous tumors from both models were characterized by flow cytometry and immunohistochemistry in hCD40tg mice. Treatment of the bladder cancer model (MB49) with ADC-1013 resulted in significant anti-tumor response and long term tumor immunity. The anti-tumor immunity was shown to be $\mathrm{T}$ cell dependent and naïve mice were protected from tumor challenge by transplantation of splenocytes from cured hCD40tg mice. In addition, significant anti-tumor effect was demonstrated in a subcutaneous B16.F10.hCD40+ melanoma model.

The human CD40 agonistic antibody ADC-1013 is the first costimulatory antibody optimized for local immunotherapy of cancer. Strong immune mediated anti-tumor

${ }^{2}$ Alligator Bioscience $A B$, Lund, Sweden

Full list of author information is available at the end of the article effects were demonstrated. ADC-1013 is currently in late pre-clinical development.

\section{Authors' details}

'Immunology, Genetics and Pathology, IGP, Uppsala University, Uppsala, Sweden. ${ }^{2}$ Alligator Bioscience AB, Lund, Sweden. ${ }^{3}$ Immunotechnology, Lund University, Sweden.

Published: 6 November 2014

\section{doi:10.1186/2051-1426-2-S3-P251}

Cite this article as: Mangsbo et al:: The human CD40 agonistic antibody ADC-1013 generates immune mediated anti-tumor effects in syngeneic tumor models in hCD40 transgenic mice. Journal for ImmunoTherapy of Cancer 2014 2(Suppl 3):P251.

Submit your next manuscript to BioMed Central and take full advantage of:

- Convenient online submission

- Thorough peer review

- No space constraints or color figure charges

- Immediate publication on acceptance

- Inclusion in PubMed, CAS, Scopus and Google Scholar

- Research which is freely available for redistribution 